\title{
Dry and Wet Atmospheric Nitrogen Deposition in West Central Africa
}

\author{
Corinne Galy-Lacaux, Claire Delon, Fabien Solmon, Marcellin Adon, \\ Véronique Yoboué, Jonas Mphepya, Jacobus J. Pienaar, Babakar Diop, \\ Luc Sigha, Laouali Dungall, Aristide Akpo, Eric Mougin, Eric Gardrat \\ and Pierre Castera
}

\begin{abstract}
This work is part of the IDAF (IGAC/DEBITS/AFrica) programme which started in 1995 with the establishment of 10 measurement sites representative of major African ecosystems. The objectives of the programme are to study wet and dry deposition fluxes, to identify the relative contribution of natural and anthropogenic sources and factors regulating these fluxes. This study presents an estimation of the atmospheric nitrogen $(\mathrm{N})$ deposition budget in Africa based on a long term monitoring measurements database including gaseous, precipitation and aerosols chemical composition. Annual nitrogen fluxes including wet and dry processes are estimated to be around $6 \mathrm{~kg} \mathrm{~N} \mathrm{ha}^{-1}$ year $^{-1}, 6.5 \mathrm{~kg} \mathrm{~N} \mathrm{ha}^{-1}$ year $^{-1}$ and
\end{abstract}

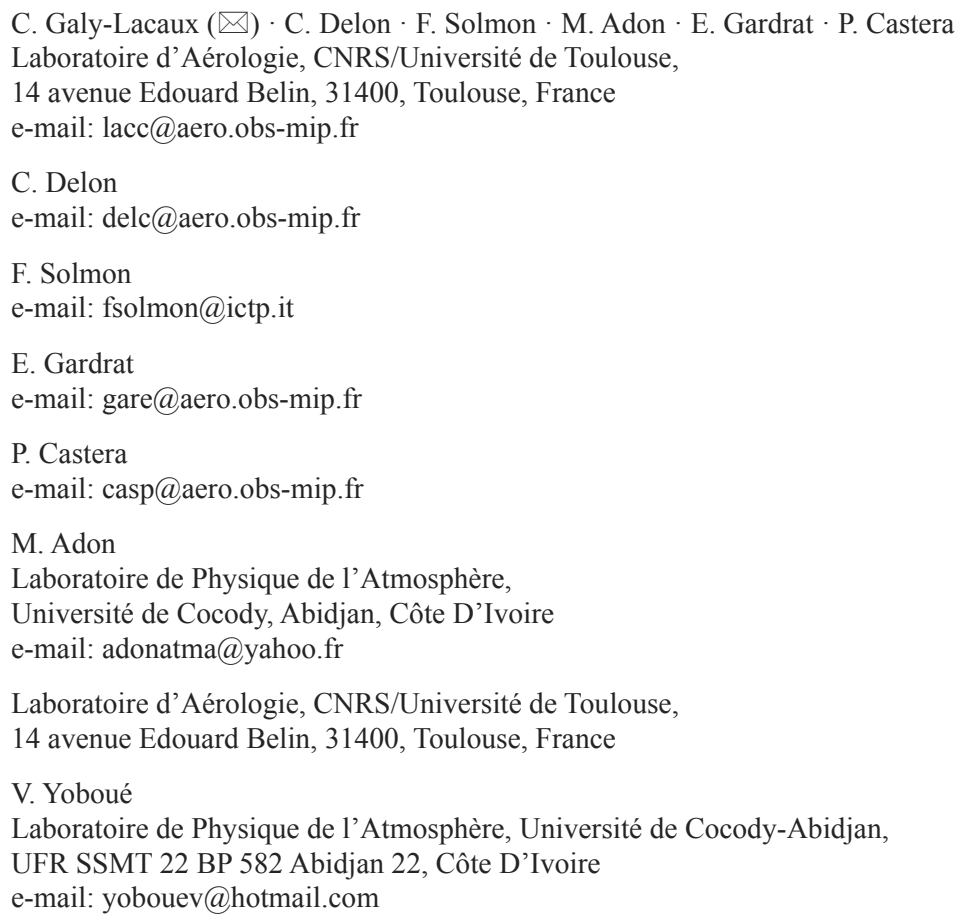


$13 \mathrm{~kg} \mathrm{~N} \mathrm{ha-1}$ year $^{-1}$ respectively over dry savanna, humid savanna and over the forest.

Keywords African ecosystems $\bullet$ Atmospheric deposition budget $\bullet$ Nitrogen $\bullet$ Wet and dry deposition

\title{
10.1 Introduction
}

The international program DEBITS (Deposition of Biogeochemically Important Trace Species) started in 1990 as part of the IGAC/IGBP (International Global Atmospheric Chemistry/International Geosphere-Biosphere Programme) " Core Project ". It is to study wet- and dry- atmospheric deposition in tropical regions (Lacaux et al. 2003). The DEBITS network includes 25 measuring stations well distributed within the tropical belt. DEBITS activities have been positively reviewed and are thus continuing within the new IGAC structure or DEBITS II (Pienaar et al. 2005; Bates et al. 2006). For tropical Africa, the IDAF (IGAC/DEBITS/AFRICA) Project started in 1994. Since IDAF has been recognized by the Institut National des Sciences de l'Univers (INSU) and the Centre National de la Recherche Scientifique (CNRS) as a part of the Environmental Research Observatory (ORE) network. ORE/IDAF has the mission of establishing a long-term measuring network to study the atmospheric composition and wet- and dry- atmospheric processes and fluxes.

\footnotetext{
J. Mphepya · J. J. Pienaar

North-West University, Potchefstroom Campus,

Private Bag X6001, Potchefstroom 2520, South Africa

e-mail: Jmphepya@environment.gov.za

J. J. Pienaar

e-mail: CHEJJP@puknet.puk.ac.za

B. Diop

Université de Bamako, Campus Universitaire de Badalabougou,

BP E2528, Bamako,

e-mail: mbbdiop@yahoo.fr

L. Sigha

Université de Yaoundé, BP 337, Yaoundé, Cameroon

e-mail: sigha_nkamdjou@yahoo.fr

L. Dungall

Université Abdou Moumouni, BP 10662, Niamey,

e-mail: laoualid@yahoo.fr
}

\author{
A. Akpo \\ Université Abomey Calavi, Cotonou, Bénin \\ e-mail: akpoarist@yahoo.fr \\ E. Mougin \\ Géosciences Environnement Toulouse, Université de Toulouse, \\ 14 avenue Edouard Belin, 31400 Toulouse, France \\ e-mail: eric.mougin@get.obs-mip.fr
}




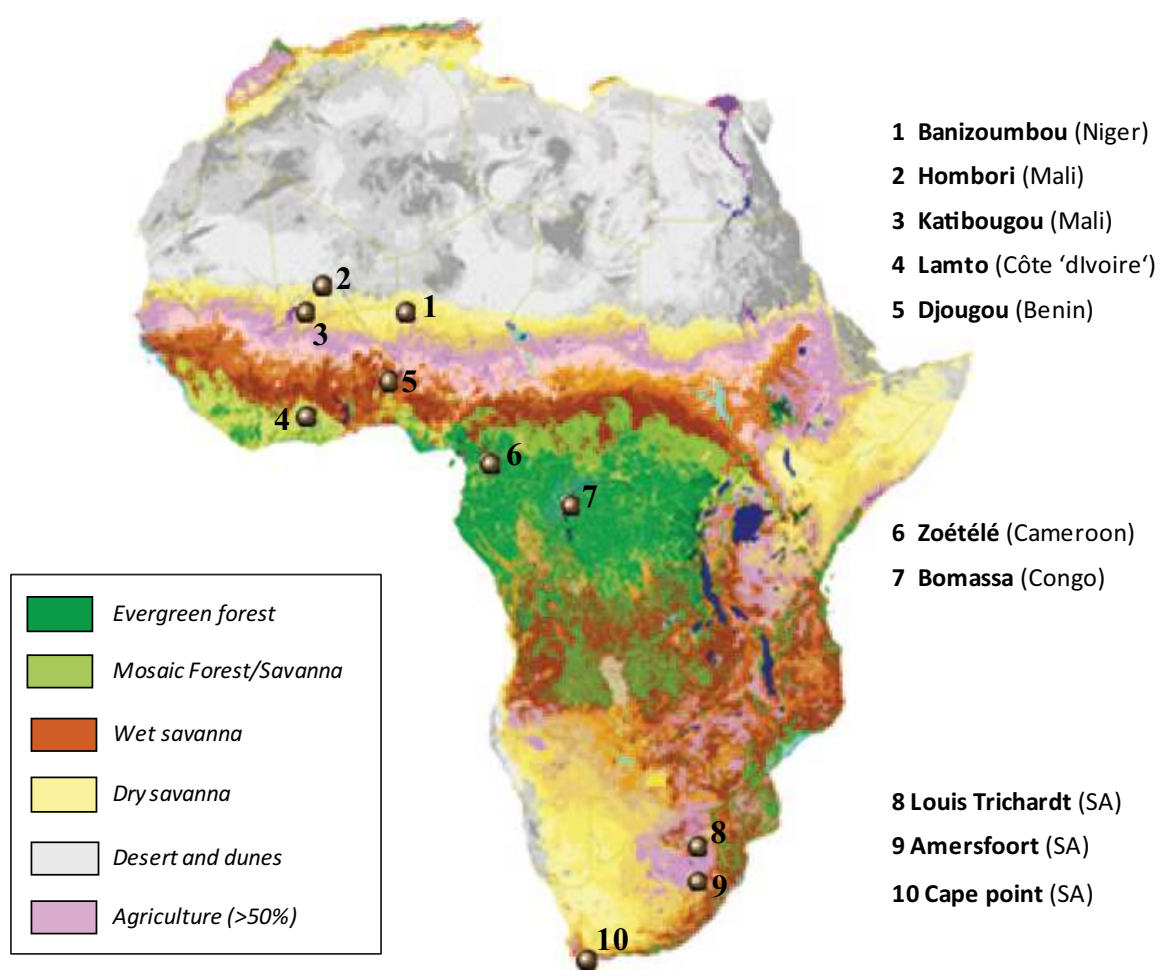

Fig. 10.1 Vegetation and location map of the 10 measurement stations of the IDAF network. Reused from Adon et al. 2010 (C) Authors 2010. CC Attribution 3.0 License)

The IDAF program is associated with the African Monsoon Multidisciplinary Analyses/Long Observation Program (AMMA/LOP, Lebel et al. 2010) over West/Central Africa and with the South African Climate Change Air Pollution-PICS (SACCLAP) Program. The main objectives of IDAF were to measure wet- and dry- deposition fluxes and identify the relative contribution of natural and anthropogenic source. In this way, the IDAF activity is based on high quality measurements of atmospheric chemical data (gaseous, precipitation and aerosols chemical composition) on the basis of a multi-year monitoring. The IDAF project implemented 8 monitoring sites covering the major African ecosystems over West and Central Africa: dry savanna (Niger, Mali, South Africa), wet savanna (Côte D'Ivoire and Benin) and equatorial forest (Cameroon, Congo) (Fig. 10.1).

\subsection{Regional Wet and Dry Nitrogen Deposition}

The objective is to present a first estimation of the atmospheric nitrogen $(\mathrm{N})$ deposition budget in West and Central Africa based on experimental measurements. To estimate atmospheric nitrogen $(\mathrm{N})$ deposition, including both wet and dry processes, 
we compiled the IDAF $\mathrm{N}$ data (gas, particles, rain) obtained from the network presented above. We studied a transect going from dry savanna to humid savanna and forest. Presenting the different component of the $\mathrm{N}$ atmospheric deposition on these sites, i.e., dry deposition in gaseous and particulate forms associated with wet deposition, this study allows the relative contribution of dry and wet deposition processes to the total $\mathrm{N}$ deposition to be given.

\subsection{Wet and Dry Deposition}

\subsubsection{Wet Deposition}

An automatic precipitation collector specially designed for the IDAF network has been installed in all stations. A local operator collects water from each rainfall event in a Greiner tube $(50 \mathrm{ml})$. Preserving the rainwater samples from contamination is an important issue since microbial input could modify its chemical composition. Samples are refrigerated at $4^{\circ} \mathrm{C}$ and preserved with $15 \mathrm{mg}$ of thymol biocide or stored in a deep freeze environment. Ion Analytical, and Ionic Chromatography procedures are given in Galy-Lacaux and Modi (1998).

The laboratory of Aerologie participate since 1996 to the international intercomparison program organized annually by WMO. According to prior results and through intercomparison tests organized by WMO, analytical precision is estimated to be $5 \%$ or better for all ions, within the uncertainties on all measured values presented here. Combining all the uncertainties of measurements and calculations, the uncertainty of the wet deposition fluxes is estimated to be about $10 \%$.

To calculate wet $\mathrm{N}$ deposition in African dry savannas, we have compiled the annual volume weighed mean concentrations of nitrate and ammonium from the precipitation collected at 5 IDAF stations. The computation of nitrate and ammonium wet deposition has been done according to a mean annual rainfall for the studied period of each sites. The mean rainfall depth registered in Banizoumbou (Niger) and Katibougou (Mali) representative of dry savannas is $632 \mathrm{~mm}$, in Lamto (Côte D'Ivoire) for wet savanna $1208 \mathrm{~mm}$ and in Zoétélé Cameroon for equatorial forests $1567 \mathrm{~mm}$.

Figure 10.2 presents annual volume weighed mean concentrations of nitrate and ammonium for selected sites and integrated periods. Mean nitrate and ammonium concentrations in the dry savannas sites measured from 1994 to 2005 in Niger and

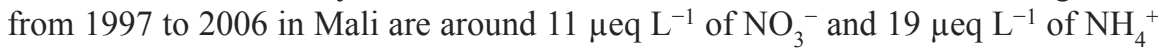
(Galy-Lacaux et al. 2009). In the wet savanna, measurements performed from 1995

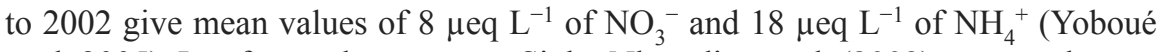
et al. 2005). In a forested ecosystem, Sigha-Nkamdjou et al. (2003) measured mean

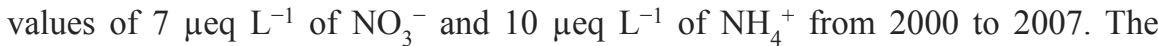
chemical composition of rain shows a strong gradient of nitrate content. In the dry savannas, biogenic emissions of $\mathrm{NO}_{\mathrm{x}}$ from soils have been identified as the major 


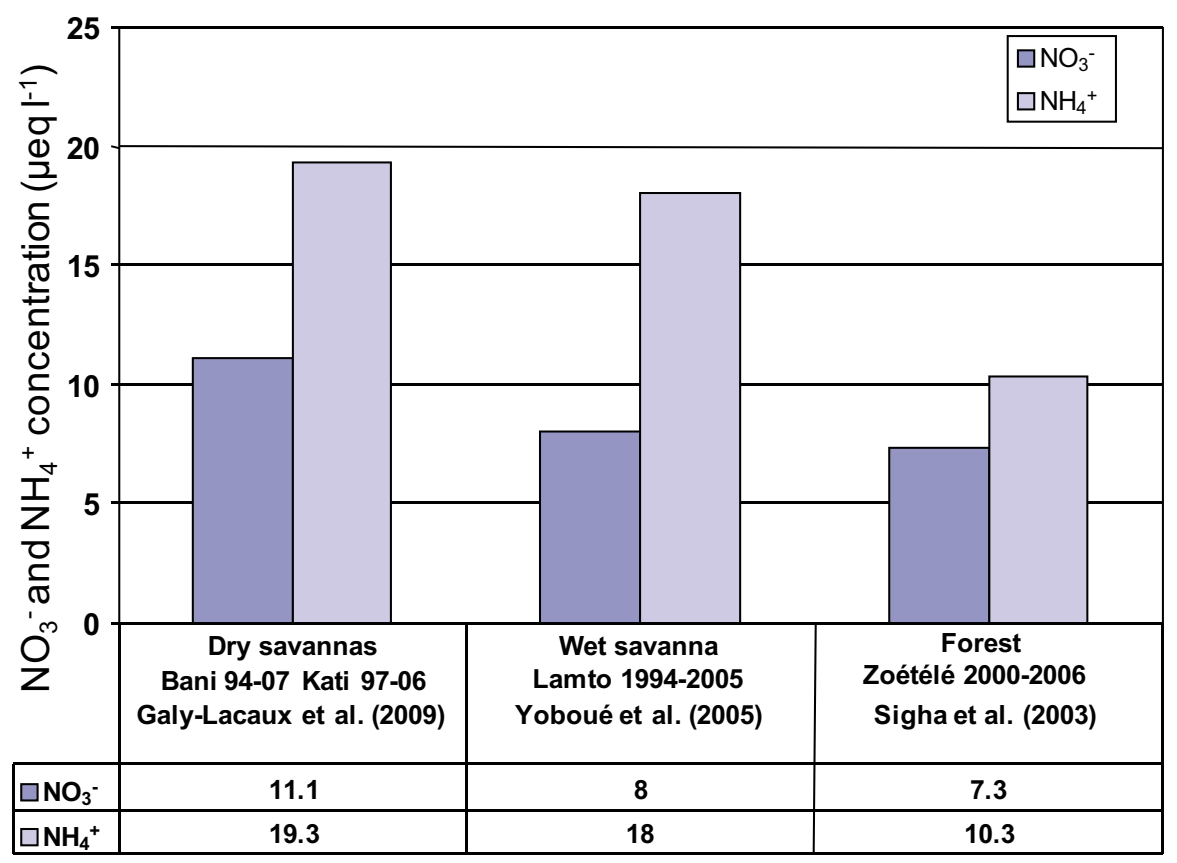

Fig. 10.2 Volume Weighed Mean (VWM) concentrations of nitrate and ammonium ( $\mu$ eq $1^{-1}$ )

contributor to the nitrate content of rain, while the high ammonium content is related to ammonia emission from animals (Serça et al. 1998; Galy and Modi 1998; Galy-Lacaux et al. 2009; Delon et al. 2010). Wet deposition of nitrate is estimated

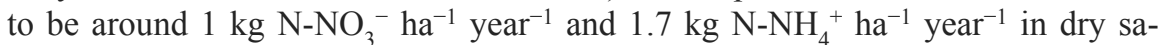
vannas, $1.4 \mathrm{~kg} \mathrm{~N}_{-} \mathrm{NO}_{3}^{-} \mathrm{ha}^{-1}$ year $^{-1}$ and $3 \mathrm{~kg} \mathrm{~N}_{-} \mathrm{NH}_{4}^{+} \mathrm{ha}^{-1}$ year $^{-1}$ in wet savannas and $2 \mathrm{~kg} \mathrm{~N}-\mathrm{NO}_{3}^{-} \mathrm{ha}^{-1}$ year $^{-1}$ and $3 \mathrm{~kg} \mathrm{~N}^{-N_{4}}{ }_{4} \mathrm{ha}^{-1}$ year $^{-1}$ in forests. The positive gradient of atmospheric nitrate and ammonium wet deposition fluxes is strongly dependent of the rainfall amounts gradient recorded along the studied ecosystems transect.

\subsubsection{Dry Deposition}

Considering the difficulties to measure directly dry deposition, the DEBITS program has adopted a strategy to infer indirect dry deposition measurements. Dry deposition is estimated on one hand from measurements of gaseous and particulate species based on continuous measurements of gaseous concentrations through passive gas sampling $\left(\mathrm{NO}_{2}, \mathrm{NH}_{3}, \mathrm{HNO}_{3}\right.$ ), and on bulk air sampling (ammonium and nitrate particulate content). On the other hand, realistic dry deposition velocity 
according to the site and the species needs to be calculated in order to estimate dry deposition fluxes.

Dry deposition of nitrogen from particles was calculated according to particulate ammonium $\left(\mathrm{pNH}_{4}^{+}\right)$and nitrate $\left(\mathrm{pNO}_{3}{ }^{-}\right)$concentrations determined in the water soluble content of the aerosols. We calculated annual mean concentrations values for the period 1998-2000. In order to estimate nitrogenous dry deposition fluxes of particles, we used a dry deposition velocity value of $1-2 \mathrm{~mm} \mathrm{~s}^{-1}$ (Whelpdale et al. 1996). The calculation shows that total dry deposition of $\left(\mathrm{pNH}_{4}^{+}\right)$and $\left(\mathrm{pNO}_{3}^{-}\right)$are of the same order of magnitude for all types of ecosystems with relatively low values. As an example, mean particle concentrations have been measured in Banizoumbou and Katibougou, and are very low: $\mathrm{pNH}_{4}{ }^{+}=0.31 \pm 0.02 \mathrm{ppb}$ and $\mathrm{pNO}_{3}{ }^{-}=0.16 \pm 0.03 \mathrm{ppb}$ in Banizoumbou, $\mathrm{pNH}_{4}{ }^{+}=0.17 \pm 0.06 \mathrm{ppb}$ and $\mathrm{pNO}_{3}{ }^{-}=0.23 \pm 0.06 \mathrm{ppb}$ in Katibougou. The other ecosystems present comparable particulate nitrate and ammonium concentrations in aerosols. The comparison of these concentrations in aerosol with gaseous $\mathrm{NH}_{3}$ concentrations in the two dry savannas sites (2.9-10.4 ppb in Banizoumbou, 1.8-6.9 ppb in Katibougou) leads to the conclusion that particulate deposition is negligible. The mean annual deposition fluxes $\left(\mathrm{pNH}_{4}^{+}+\mathrm{pNO}_{3}^{-}\right)$in the semiarid, wet savanna and forested ecosystems are around $0.3,0.4$ and $0.06 \mathrm{~kg} \mathrm{~N} \mathrm{ha}^{-1}$ year $^{-1}$, respectively. One should note that particulate dry deposition of nitrogen is smaller by an order of magnitude than the wet deposition.

Gaseous dry deposition of nitrogen has been calculated as the sum of dry deposition fluxes of ammonia $\left(\mathrm{NH}_{3}\right)$, nitric acid $\left(\mathrm{HNO}_{3}\right)$ and nitrogen oxide $\left(\mathrm{NO}_{2}\right)$. Gaseous measurement $\left(\mathrm{NH}_{3}, \mathrm{HNO}_{3}, \mathrm{NO}_{2}\right)$ are monthly integrated samples using passive sampling techniques following the work of Ferm (1994). This technique has been tested in different tropical and subtropical region (Ferm and Rodhe 1997; Carmichael et al. 2003; Martins et al. 2007). Adon et al. (2010) presents ten year of gases monitoring on 7 IDAF sites. Mean annual concentrations from the whole database have been performed. Figure 10.3 presents the mean annual concentrations of $\mathrm{NO}_{2}, \mathrm{HNO}_{3}$ and $\mathrm{NH}_{3}$ for the different IDAF sites measured over the period 1997-2007. Concentrations are ranged from 1 to $2 \mathrm{ppb}$ for $\mathrm{NO}_{2}$, from 0.2 to $0.5 \mathrm{ppb}$ for $\mathrm{HNO}_{3}$ and from 3.5 to $6 \mathrm{ppb}$ for $\mathrm{NH}_{3}$, respectively.

The major uncertainty in the estimation of trace gases dry deposition is due to the computation of the dry deposition velocity. Monthly dry deposition velocities have been calculated for 4 years $(2002,2003,2004$ and 2006) to follow the monthly seasonal cycle of measured gases (Delon et al. 2010). In the present work, we have calculated annual means of deposition velocities for $\mathrm{NO}_{2}, \mathrm{HNO}_{3}$ and $\mathrm{NH}_{3}$ for each ecosystem type. Annual deposition velocities (2002-2006) range from 2 to $5 \mathrm{~mm} \mathrm{~s}^{-1}$ for $\mathrm{NO}_{2}$, from 6 to $18 \mathrm{~mm} \mathrm{~s}^{-1}$ for $\mathrm{HNO}_{3}$ and from 2 to $8 \mathrm{~mm} \mathrm{~s}^{-1}$ for $\mathrm{NH}_{3}$. We estimate the total uncertainty applied to the dry $\mathrm{N}$ fluxes. The uncertainties are mainly linked to the concentration measurements and the estimation of the deposition velocities. For dry deposition of gases, the total rate of uncertainty applied for deposition fluxes is $70 \%$ for $\mathrm{NO}_{2}, 31 \%$ for $\mathrm{NH}_{3}$ and $38 \%$ for $\mathrm{HNO}_{3}$.

$\mathrm{NO}_{2}$ dry deposition fluxes presents a small variability according to the type of ecosystem, with fluxes varying from $0.5 \mathrm{~kg} \mathrm{~N}^{-1}$ year $^{-1}$ in the wet savanna, $0.82 \mathrm{~kg} \mathrm{~N} \mathrm{ha}^{-1}$ year $^{-1}$ in the dry savanna, to $1 \mathrm{~kg} \mathrm{~N} \mathrm{ha}^{-1}$ year $^{-1}$ in forested ecosystem. 


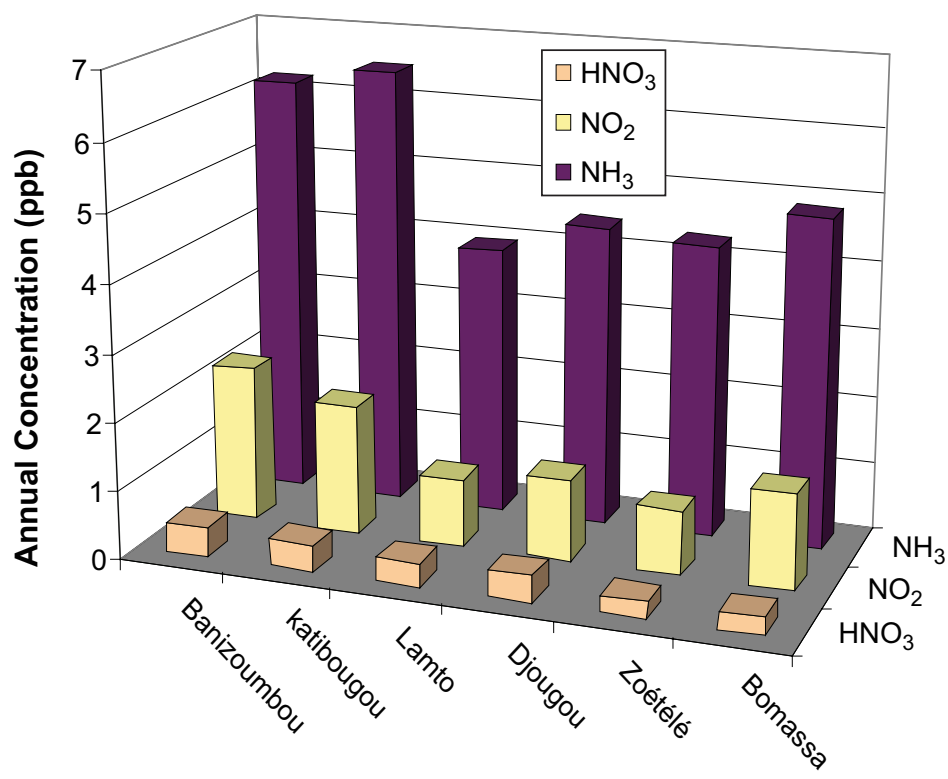

Fig. 10.3 Annual mean concentrations of nitric acid, ammonia and nitrogen dioxide over the period 1997-2007 in part per billion by volume (ppb). (Adon et al. 2010)

$\mathrm{NH}_{3}$ dry deposition fluxes present higher values with 2 and $2.3 \mathrm{~kg} \mathrm{~N}^{-1} \mathrm{year}^{-1}$ in dry savanna and wet savanna, respectively and $6 \mathrm{~kg} \mathrm{~N} \mathrm{ha}^{-1}$ year $^{-1}$ over the forest. Major sources of $\mathrm{NH}_{3}$ include bacterial decomposition from urea in animal excreta and emissions by natural or fertilized soils (Schlesinger and Hartley 1992). In Africa, another significant source of ammonia is produced by savanna fires and domestic fuelwood burning (Delmas et al. 1995). Dry deposition fluxes of $\mathrm{HNO}_{3}$ are very low compared with $\mathrm{NO}_{2}$ and $\mathrm{NH}_{3}$, with values ranged between 0.4 and $0.8 \mathrm{~kg} \mathrm{~N} \mathrm{ha}^{-1}$ year $^{-1}$ for all the ecosystems. This result is correlated to very low $\mathrm{HNO}_{3}$ concentrations measured on all the stations.

\subsection{Nitrogen Deposition Budget}

Dry deposition fluxes, estimated for the three African ecosystems were combined with those associated with wet deposition to provide a first estimate in western-central Africa for the annual nitrogen atmospheric deposition. The total $\mathrm{N}$ deposition is estimated to be around $6 \mathrm{~kg} \mathrm{~N}^{-1}$ year $^{-1}, 6.5 \mathrm{~kg} \mathrm{~N}^{-1}$ year $^{-1}$ and $13 \mathrm{~kg} \mathrm{~N} \mathrm{ha}^{-1}$ year $^{-1}$ respectively over dry savanna, humid savanna and over the forest. These values should be taken with caution and we estimated the uncertainties on the budget to be around $30 \%$. If the estimations of wet deposition fluxes are known within a $10 \%$ margin, dry deposition fluxes present larger uncertainties mainly due to dry 
deposition calculation. It is also important to note that our budget does not take into account all nitrogenous species, especially organic $\mathrm{N}$ species.

An important result highlighted by this budget is the importance of dry deposition processes in West Central Africa, especially for nitrogenous gaseous compounds. In dry savanna and forest, the relative contribution of dry deposition is about $60 \%$. In the wet savanna the contribution is around $50 \%$.

Acknowledgments This work is part of the IDAF (IGAC/DEBITS/AFRICA) project; and was funded by INSU/CNRS "Institut National des Sciences de l'Univers/Centre National de Recherche Scientifique" and the API "African Monsoon Multidisciplinary Analysis" (AMMA in 2005). The authors are grateful to all the field technicians at the African station and IRD (Institut de Recherche pour le Developpement) for logistical support.

\section{References}

Adon, M., Galy-Lacaux, C., Yoboué, V., Delon, C., Lacaux, J. P., Castera, P., Gardrat, E., Pienaar, J., Al Ourabi, H., Laouali, D., Diop, B., Sigha-Nkamdjou, L., Akpo, A., Tathy, J. P., Lavenu, F., \& Mougin, E. (2010). Long term measurements of sulfur dioxide, nitrogen dioxide, ammonia, nitric acid and ozone in Africa using passive samplers. Atmospheric Chemistry and Physics, 10, 7467-7487.

Bates, T., Scholes, M., Doherty, S., \& Young, B. (Eds.). (2006). IGAC Science Plan \& Implementation Strategy IGBP Report 56.

Carmichael, G. R., Ferm, M., Thongboonchoo, N., Woo, J.-H., Chan, L. Y., Murano, K., Viet, P. H., Mossberg, C., Bala, R., Boonjawat, J., Upatum, P., Mohan, M., Adhikary, S. P., Shrestha, A. B., Pienaar, J. J., Brunke, E. B., Chen, T., Jie, T., Guoan, D., Peng, L. C., Dhiharto, S., Harjanto, H., Jose, A. M., Kimani, W., Kirouane, A., Lacaux, J. P., Richard, S., Barturen, O., Cerda, J. C., Athayde, A., Tavares, T., Cotrina, J. S., \& Bilici, E. (2003). Measurements of sulfur dioxide, ozone and ammonia concentrations in Asia, Africa, and South America using passive samplers. Atmospheric Environment, 37, 1293-1308.

Delmas, R. A., Lacaux, J. P., Menaut, J. C., Abbadie, L., Le Roux, X., Helas, G., \& Lobert, G. (1995). Nitrogen compound emission from biomass burning in tropical African savanna, FOS/DECAFE 91 Experiment (Lamto, Ivory Coast). Journal of Atmospheric Chemistry, 22, 175-194.

Delon, C., Galy-Lacaux, C., Boone, A., Liousse, C., Serça, D., Adon, M., Diop, B., Akpo, A., Lavenu, F., Mougin, E., \& Timouk, F. (2010). Atmospheric nitrogen budget in Sahelian dry savannas. Atmospheric Chemistry and Physics, 10, 2691-2708.

Ferm, M., \& Rodhe, H. (1997). Measurements of air concentrations of $\mathrm{SO}_{2}, \mathrm{NO}_{2}$ and $\mathrm{NH}_{3}$ at rural and remote sites in Asia. Journal of Atmospheric Chemistry, 27, 17-29.

Ferm, M., Lindskog, A., Svanberg, P.-A., \& Boström, C.-A. (1994). New measurement technique for air pollutants. Kemisk Tidskrift, 1, 30-32 (in Swedish).

Galy-Lacaux, C., \& Modi, A. I. (1998). Precipitation chemistry in the Sahelian Savanna of Niger, Africa. Journal of Atmospheric Chemistry, 30, 319-334.

Galy-Lacaux, C., Laouali, D., Descroix, L., Gobron, N., \& Liousse, C. (2009). Long term precipitation chemistry and wet deposition in a remote dry savanna site in Africa (Niger). Atmospheric Chemistry and Physics, 9, 1579-1595.

Lacaux, J. P., Tathy, J. P., \& Sigha, L. (2003) Acid wet deposition in the tropics: two case studies using DEBITS measurements. IGACtivities Newsletter of the International Global Atmospheric Chemistry Project, DEBITS Special Issue $N^{\circ} 2$. 
Lebel, T., Parker, D. J., Flamant, C., Bourlès, B., Marticorena, M., Mougin, E., Peugeot, C., Diedhiou, A., Haywood, J. M., Ngamini, J. B., Polcher, J., Redelsperger, J.-L., \& Thorncroft, C. D. (2010). The AMMA field campaigns: Multiscale and multidisciplinary observations in the West African region. Quarterly Journal of the Royal Meteorological Society 136(S1), 8-33.

Pienaar, J. J. (2005). Proposal of a new IGAC II task: DEBITS II (Deposition of Biogeochemically Important Trace Species). http://igac.jisao.washington. edu/DEBITS.php.

Martins, J. J., Dhammapala, R. S., Lachmann, G., Galy-Lacaux, C., \& Pienaar, J. J. (2007). Longterm measurements of sulphur dioxide, nitrogen dioxide, ammonia, nitric acid and ozone in southern Africa using passive samplers. South African Journal of Science, 103(7-8), 336-342.

Schlesinger, W. H., \& Hartley, A. E. (1992). A global budget for atmospheric ammonia. Biogeochemistry, 15, 191-211.

Serça, D., Delmas, R., Le Roux, X., Parsons, D. A. B., Scholes, M. C., Abbadie, L., Lensi, R., Ronce, O., \& Labroue, L. (1998). Comparison of nitrogen monoxide emissions from several African tropical ecosystems and influence of season and fire. Global Biogeochemical Cycles, 12, 637-651.

Sigha-Nkamdjou, L., Galy-Lacaux, C., Pont, V., Richard, S., Sighoumnou, D., \& Lacaux, J. P. (2003). Rainwater chemistry and wet deposition over the equatorial forested ecosystem of Zoétélé (Cameroon). Journal of Atmospheric Chemistry, 46, 173-198.

Whelpdale, D. M., Summers, P. W., \& Sanueza, E. (1996). A global overview of atmospheric acid deposition fluxes. Environmental Monitoring and Assessment, 48, 217-247.

Yoboue, V., Galy-Lacaux, C., Lacaux, J. P., \& Silue, S. (2005). Rainwater chemistry and wet deposition over the wet savanna ecosystem of Lamto (Côte D'Ivoire). Journal of Atmospheric Chemistry, 52, 117-141. 